\title{
COMPARATIVE STUDY OF HISTOLOGICAL AND HISTOCHEMICAL PROPERTIES OF PERITONEAL MAST CELLS OF ALBINO RAT USING TWO TYPES OF FIXATIVES
}

\author{
KAMTA PRASAD NIRALA*, SUBHASH GUPTA
}

Department of Anatomy, Varun Arjun Medical College and Rohilkhand Hospital, Banthara, Shahjahanpur, Uttar Pradesh, India. Email: kamtanirala7@gmail.com

Received: 19 March 2021, Revised and Accepted: 28 April 2021

\section{ABSTRACT}

Objectives: To make a comparative study of histological and histochemical properties of peritoneal mast cells in albino rat using neutral buffered formalin and formal alcohol as fixatives.

Methods: The stretch preparation from Albino rat peritoneum was made on chemically clean glass slides and immediately placed into the fixatives.

Results: With toluidine blue ( $\mathrm{pH} 4.4$ ), the mast cells stained deep purple and similar reaction was obtained with toluidine blue at pH 2. These staining reactions indicate the presence of substantial amount of heparin trisulfate, small amount of heparin monosulfate, and neutral mucopolysaccharide.

Conclusion: Heparin trisulfate is an active form of heparin and is the main constituent of the mast cell granules of the albino rat.

Keywords: Peritoneal mast cells, Albino rat, Heparin, Histochemistry.

(C) 2021 The Authors. Published by Innovare Academic Sciences Pvt Ltd. This is an open access article under the CC BY license (http://creativecommons.org/ licenses/by/4.0/) DOI: http://dx.doi.org/10.22159/ajpcr.2021v14i6.41513. Journal homepage: https://innovareacademics.in/journals/index.php/ajpcr

\section{INTRODUCTION}

The identification of mast cell as a source of heparin came 60 years after its discovery by Ehrilich in 1877 [1], preceded by the recognition of the cell by Recklinghausen in 1863 [2], as well as by Waldeyer. Still, they could hardly identify this cell as a mast cell. No single cell in the human body has such varied functions as a mast cell, yet it is a fact that it took 60 long years to get the first knowledge of its process. In 1907, Michels [3] stated that it many contain chondroitin sulfuric acid. Ehrlich himself believed in the functional importance of this cell and especially of its granule content, whose staining reaction with basic aniline dyes led him to coin the word "Metachromasia." With the discovery of heparin 1937 [4], followed by the discovery of histamine 1953 [5], hyaluronic acid 1954 [6], and 5-hydroxytryptamine 1955 [7] and several other enzymes later, its importance was identified. The mast cell is also considered a source of slow-reacting substance. Eventually, mast cell is a pluripotent cell that contains several compounds that tissue may need, especially in the region exposed to local stress (Selye, 1965) [8].

\section{METHODS}

\section{Study design}

This was a laboratory-based experimental study.

\section{Study population}

Rattus norvegicus (Albino rat).

Data instrument

- Neutral buffered formalin

- Formal alcohol

- Toluidine blue

- PAS.

- Aldehyde fuchsin

- Alcian blue pH - 1.0

- Alcian blue $\mathrm{pH}-2.5$.

Statistical analysis

Microsoft Excel was used for recording and analyzing the data.

\section{Methodology}

Biopsy

The Albino rat was anesthetized in the laboratory under closed chloroform anesthesia. The abdomen was opened vertically from the xiphoid process to pubic symphysis. Jejunum and ileum were identified. The stretch preparation was made on chemically clean glass slides and immediately placed into the fixatives.

Fixation

The following fixative was used for the fixation of stretch preparation and tissues.

Neutral buffered formalin ( $\mathrm{pH}-7.0)$

- $\quad \mathrm{Na} \mathrm{H}_{2} \mathrm{PO}_{4} 2 \mathrm{H}_{2} \mathrm{O}(4.52 \mathrm{~g})+\mathrm{Na}_{2} \mathrm{HPO}_{2} 2 \mathrm{H}_{2} \mathrm{O}$ (8.15 g)

- Analytical formalin $\quad-1000 \mathrm{ml}$

- Distilled water $-900 \mathrm{ml}$.

Formal alcohol

- $10 \%$ formalin in absolute alcohol

- Formalin $-10 \mathrm{ml}$

- Absolute alcohol- $90 \mathrm{ml}$

The stretch preparations of tissues were fixed for $24 \mathrm{~h}$ in formal alcohol and neutral buffered formalin. The stretch preparations were directly subjected to different staining procedures and fixed in neutral buffered formalin, then dehydrated in ascending grades of alcohol; while tissues fixed in formal alcohol were directly brought to dehydrated alcohol, For histochemical tests the following staining procedures were used.

1. For highly sulfated acid mucopolysaccharides

a. Alcian blue $\mathrm{pH}-1.0$ (Lev and Spicer, 1964) [9]

b. Alcian blue $\mathrm{pH}-1.0$ (after active methylation Spicer et al., 1967) [10]

c. Aldehyde fuchsin (Spicer and Meyer, 1960) [11]

2. For weakly sulfated A.M.P. (Acid mucopolysaccharide)

a. Alcian blue $\mathrm{pH}-2.5$ (Spicer et al., 1967) [10]

b. Alcian blue $\mathrm{pH}-2.5$ after mild methylation (Spicer et al., 1967) [10] 
Table 1: Histochemical reactions of mast cells in the mesentery of albino rat fixed in different fixatives

\begin{tabular}{|c|c|c|c|c|c|c|c|c|c|c|c|}
\hline \multirow[t]{2}{*}{ Fixatives } & \multicolumn{2}{|c|}{ TB at pH } & \multicolumn{2}{|c|}{ AB at pH 2.5} & \multicolumn{2}{|c|}{ AB at pH 1.0} & \multirow[t]{2}{*}{$\mathbf{A F}$} & \multirow{2}{*}{$\frac{\mathbf{A F}}{\mathrm{AB} \mathrm{pH} 2.5}$} & \multirow[t]{2}{*}{ PAS } & \multirow{2}{*}{$\frac{\mathrm{AB}}{\mathrm{pH} 2.5-\mathrm{PAS}}$} & \multirow{2}{*}{$\begin{array}{l}\text { AB pH } 1.0 \\
-P A S\end{array}$} \\
\hline & 4.4 & 2.0 & UT & Mild Meoh & Ut & Active Meoh & & & & & \\
\hline $\mathrm{NBF}$ & $4 p$ & $3 p$ & $3 B$ & $1 \mathrm{~B}$ & $2 \mathrm{~B}$ & $1 \mathrm{~B}$ & $4 \mathrm{P}$ & $3 \mathrm{P}$ & 0 & $2 \mathrm{~B}$ & $2 \mathrm{~B}$ \\
\hline FA & $4 \mathrm{P}$ & $4 \mathrm{P}$ & $3 \mathrm{~B}$ & $1 \mathrm{~B}$ & $3 \mathrm{~B}$ & $1 \mathrm{~B}$ & $3 \mathrm{P}$ & $3 \mathrm{P}$ & 0 & $3 R$ & $2 \mathrm{~B}, 3 \mathrm{R}$ \\
\hline
\end{tabular}

3. For simultaneous demonstration of highly and weakly sulfated acid mucopolysaccharides

a. Aldehyde fuchsin - Alcian blue $\mathrm{pH}-2.5$ Procedure

4. For simultaneous demonstration of sulfated and neutral mucopolysaccharides

a. PAS - Procedure

b. Alcian blue $\mathrm{pH}-1.0$ - PAS procedure

c. Alcian blue $\mathrm{pH}-2.5-\mathrm{PAS}$ procedure

5. Toluidine blue for metachromatic properties at different $\mathrm{pH}$

a. At $\mathrm{pH}-2.0$

b. At $\mathrm{pH}-4.4$

\section{RESULTS}

Morphology and distribution of mast cells of Albino rat

A. Neutral buffered formalin

Mast cells were present 10-12/high-power field (hpf) in toluidine blue stained material but were about $20-22 / \mathrm{hpf}$ in aldehyde fuchsin stained mesentery. They were hardly $7 / \mathrm{hpf}$ in Alcian blue stained material at $\mathrm{pH} 2.5$. The mast cells were mostly oval with a central unstained nucleus and the cytoplasm was filled with metachromatic coarse granules. The granules were deep purple.

\section{B. Formal alcohol}

The mast cells were 12-13/hpf in toluidine blue stained mesentery. Here also, the mast cells were mostly oval with deep purple metachromatic granules. In some mast cells, the granules were seen outside the cell membrane which was probably due to mechanical handling during stretch preparation.

A. Different types of mucopolysaccharides in peritoneal mast cells Albino rat (Table 1).

1. Neutral buffered formalin

- With this fixative, the mast cells stained deep purple with toluidine blue at $\mathrm{pH} 4.4$ and moderate purple with toluidine blue at $\mathrm{pH}$ 2. With Alcian blue at $\mathrm{pH} 2.5$, the mast cells stained moderate blue and this alcianophilia was greatly reduced by mild methylation

- With Alcian blue pH 1, they stained light blue and this alcianophilia was reduced after active methylation. With aldehyde fuchsin, Alcian blue $\mathrm{pH} 2.5$, the mast cells stained moderate purple. They were unreactive to PAS staining procedure but stained light blue with Alcian blue pH 2.5 PAS and Alcian blue $\mathrm{pH} 1 \mathrm{PAS}$ procedure.

2. Formal alcohol

- With toluidine blue $\mathrm{pH} 4.4$, the mast cells stained deep purple and similar reaction was obtained with toluidine blue at $\mathrm{pH} 2$

- With Alcian blue pH 2.5, the mast cells stained moderate blue and also gave similar reaction with Alcian blue at $\mathrm{pH} 1$. This alcianophilia was reduced to faint blue after mild methylation in the former and active methylation in the latter

- With aldehyde fuchsin, they stain moderate purple; and with aldehyde fuchsin - Alcian blue $\mathrm{pH} 2.5$ also, they give moderate purple reaction. The mast cells were unreactive to PAS. staining procedure but stained moderate red with Alcian blue pH 2.5 PAS stain

- With Alcian blue pH 1 PAS. staining, some mast cells stained light blue while others gave the moderate red reaction
- These staining reactions indicate the presence of substantial amount of heparin trisulfate and small amount of heparin monosulfate and neutral mucopolysaccharide.

\section{DISCUSSION}

Ehrilich (1877) [1] who discovered mast cells noted that the mast cell granules were highly soluble in aqueous fixation in some species of animals while in others, this was not so. He suggested that the tissue for mast cell study must be fixed in $50 \%$ alcohol and then stained in alcoholic thiamine.

Holmgren, 1938 [12], used 4\% basic lead sub-acetate for the fixation of mast cells and Mota et al. (1956) used basic lead sub-acetate in 50\% alcohol with acetic acid.

Padawer, 1959 [13], used non-aqueous fixative which was a combination of absolute alcohol and formaldehyde.

In the present work, the identification of mast cell is based on metachromatic reaction of its granules with acidified toluidine blue at $\mathrm{pH} 2$, buffered toluidine blue at $\mathrm{pH} 4.4$, and aldehyde fuchsin and Alcian blue at $\mathrm{pH}$ 2.5. Toluidine blue has been used at two different $\mathrm{pH}$ levels to identify both types of mast cell granules containing both lower and higher sulfates of heparin. Heparin trisulfate has greater affinity for toluidine blue at low $\mathrm{pH}$ while at higher $\mathrm{pH}$, even the monosulfate form of heparin reacts with the dye Lannert and Schubert, 1959 [14], and Combs et al., 1965 [8], suggested that the purple to red-purple color of rat mast cell granule is due to higher sulfate of heparin. Maturation of mast cell granules begins with sulfation of heparin in the immature cells. Initially, the heparin has only one sulfate molecule in immature mast cell granules but as these granules mature the number of sulfate group increases and in fully mature mast cells, the heparin is found in trisulfate form.

In the present work, most of the mast cells observed are stained purple in different degrees and as such have not caused any problem in identifying them. Apart from toluidine blue metachromasia, aldehyde fuchsin and Alcian blue at $\mathrm{pH} 2.5$ staining have also been taken into account for the identification of mast cells.

\section{CONCLUSION}

Observations were made on histochemical properties of mast cells in two fixatives; namely, neutral buffered formalin in phosphate buffer at pH 7 and 10\% formalin in absolute alcohol (formol alcohol); in both stretch preparation and microtome sections. They have been subjected to a battery of historical staining procedures to determine the chemical nature of heparin as well as the presence of neutral mucopolysaccharide in the peritoneal mast cells of different animals under study.

1. Heparin trisulfate is an active form of heparin and is the main constituent of the mast cell granules of albino rat

2. Heparin monosulfate is present in small amount.

\section{Clinical relevance}

Heparin as well as the neutral mucopolysaccharide are present in the peritoneal mast cells. Mast cells play a central role in the pathophysiology of various allergic diseases in the respiratory tract and gastrointestinal tract

\section{ACKNOWLEDGMENT}

We acknowledge the kind support of college administration and supporting staff in helping us to carry out the study in systematic and cordial manner. 


\section{AUTHORS' CONTRIBUTIONS}

Both authors contributed equally.

\section{CONFLICTS OF INTEREST}

None.

\section{AUTHORS' FUNDING}

Self.

\section{REFERENCES}

1. Ehrilich P. Beitrage zur kenntnis der anilinfarbungen und iherverwen dung in der mikroskepischen techik. Arch Micro Anat 1877;13:263-7.

2. von Recklighausen F. Uber eiter-RND bindegewebs korperchen Virchows arch. Path Anat 1863;28:157.

3. Schaffer J. Preparated von lockerem subkutangewebe. Ztrbl Physoil 1907;21:258.

4. Michels NA. The mast cells. In: Downey Handbook of Haematology. Vol. 1. New York: P. B. Hoeber Inc.; 1937. p. 232.
5. Riely JF, Saepherd DM, West GB, Stroud SW. Function of heparin. Nature 1953;176:1123.

6. Asboe-Hansen G. The mast cell. Int Rev Cytol 1954;3:399-435.

7. Benditt EP, Wong RL, Arase M, Roeper E. 5-hydroxytryptamine in mast cells. Proc Soc Exp Biol Med 1955;90:303-4.

8. Combs JW, Lagunoff D, Benditt EP. Differentiation of embryonic mast cells of rat. J Cell Biol 1965;25:577-92.

9. Adams-Ray J. Mast cells and monoamines. Experientia 1964;20:80-2.

10. Spicer SS, Horn RG, Leppi TJ. The Connective Tissue. Baltimore: The Williams and Wilkins Co.; 1967. p. 251-303.

11. Spicer SS. A correlative study of the histochemical properties of rodent acid mucopolysaccharides. J Histochem Cytochem 1960;8:18-35.

12. Holmgren H. Eineneue Methods Zurfixierung der Ehrlichschen Mastzellen, Mitbesonderer Berucksichtigung der Chemic der Zellgrunula; 1938.

13. Padawer J. A stain for mast cells and its applications in various vertebrates and mastocytoma. J Histochem Cytochem 1959;7:352-3.

14. Lannert K, Schubert JC. Untersuchungenuber die Sauren MucopolysaccharidedeGewemastzellenimmenschilichenkncehenmark. Fankf Ztscher Pathol 1959;69:579. 